\title{
ANALISIS RISIKO FLIGHT DELAY PENGIRIMAN BARANG SAAT COVID-19 DI PT LESCHACO LOGISTIC INDONESIA DENGAN METODE HOUSE OF RISK
}

\author{
Dani Leonidas Sumarna ST., MT. $\left.{ }^{1}\right)$,Fauzaan Muhamad Nabil. ${ }^{2}$ ) \\ ${ }^{1}$ D4 Logistik Bisnis, Politeknik Pos Indonesia \\ email: danileo@poltekpos.ac.id \\ ${ }^{2}$ D4 Logistik Bisnis, Politeknik Pos Indonesia \\ email: fauzannabil11@gmail.com
}

\begin{abstract}
Abstrak
Saat ini Indonesia sedang mengalami masa pandemi virus terbaru yaitu Coronavirus Disease -19 (Covid-19) yang telah merugikan beberapa sektor perekonomian seperti industri manufaktur, pariwisata, logistik, transportasi dan lain-lain. PT Leschaco merupakan perusahaan yang bergerak di bidang logistik freight forwarding yang menyediakan jasa pengiriman seperti air freight, sea freight, tank container, warehouse, dan contract logistic. Selama pandemi ada beberapa permasalahan yang timbul dalam pengiriman melalui air freight salah satunya yaitu flight delay yang mengakibatkan keterlambatan pengiriman barang, dari kegiatan tersebut timbul kejadian risiko yang harus diidentifikasi terlebih dahulu agen risikonya untuk bisa dilakukan proses aksi mitigasi. Tujuan penelitian ini adalah untuk mengetahui dan memitigasi risiko dalam proses pengiriman barang saat covid-19 PT Leschaco Logistic Indonesia.

Penelitian ini menggunakan metode House of Risk (HOR) untuk mengidentifikasi variabel risiko dan mitigasi risiko. House of Risk merupakan pengembangan metode failure Modes and Effect Analysis (FMEA) dan Quality Function Operation Deployment (QFD). Proses metode House of Risk dibagi menjadi dua fase: pertama yaitu identifikasi risiko untuk menghasilkan prioritas risk agent. Kedua adalah penyusunan tindakan pencegahan untuk menghasilkan preventive action yang efektif. Hasil penelitian menunjukkan terdapat 25 kejadian risiko, 38 agen risiko semua agen risiko tersebut diolah kembali untuk menentukan agen risiko yang prioritas dan non prioritas. Agen risiko prioritas sebanyak 13 agen risiko dan agen risiko non prioritas sebanyak 25. Tindakan pencegahan yang dilakukan untuk memitigasi agen risiko prioritas sebanyak 19 aksi mitigasi.
\end{abstract}

\section{Kata Kunci: House of Risk, Transportasi, Covid-19, Freight Forwarding, Risiko.}

\section{PENDAHULUAN}

Saat ini Indonesia sedang mengalami masa pandemi virus terbaru yaitu Coronavirus Disease -19 (Covid-19) yang telah menelan banyak korban, di tengah pandemi ini kondisi ekonomi menjadi hancur dan terjadi penurunan di berbagai sektor seperti industri manufaktur, pariwisata, logistik, transportasi dll. Dengan adanya wabah Covid-19 ini mengakibatkan perusahaan harus mengurangi jumlah karyawan yang beroperasi guna mengaplikasikan pyhsical distancing untuk menghentikan penyebaran virus ini, akibatnya kegiatan operasional perusahaan terhambat karena kekurangan sumber daya manusia. Sumber daya manusia sangatlah vital untuk perusahaan karena sebagai pelaku dari keseluruhan kegiatan tingkat perencanaan sampai dengan evaluasi.

PT Leschaco Logistic Indonesia adalah salah satu perusahaan freight forwader yang bergerak di bidang jasa ekspor dan impor serta penyedia jasa logistik seperti air freight, sea freight, warehouse, dan tank container yang telah mempunyai pengalaman, berdedikasi, serta semangat untuk selalu berinovasi. PT Leschaco Logistic Indonesia telah memiliki banyak pelanggan yang telah mempercayakan untuk menangani kegiatan logistik mereka, sehingga sebagai perusahaan yang menangani jasa ekspor impor sudah seharusnya perusahaan dapat mengutamakan pelayanan yang baik. Namun pada kenyatannya proses bisnis perusahaan tidak selalu berjalan 
dengan baik, masih terdapat kendala yang dihadapi dalam menjalankan proses bisnis perusahaan, terutama dalam kegiatan ekspor impor.

Secara umum risiko dapat timbul dalam berbagai bentuk dari setiap kejadian. Risiko merupakan peluang terjadinya sesuatu yang akan berdampak dalam pencapaian tujuan. Kompleksitas dari struktur yang melibatkan banyak pihak dan banyaknya ketidakpastian yang terjadi secara mendadak menjadi tantangan dalam pengelolaan perusahaan. Manajemen risiko sangat diperlukan dalam penangangan risiko dengan tujuan untuk meminimalisasi tingkat risiko dan dampak dari risiko tersebut (Hanafi dalam Abyan, 2019).

Tanpa adanya penanganan risiko yang baik tentu dapat mengancam kelangsungan bagi bisnis perusahaan, oleh karena itu pengelolaan risiko yang baik sangatlah penting bagi perusahaan. Sehingga pada penelitian ini akan dilakukan analisis terhadap resiko yang dapat terjadi menggunakan metode House Of Risk (HOR) untuk mengetahui penyebab apa saja yang berpotensi timbul dalam proses bisnis perusahaan dan mengetahui bagaimana perancangan strategi mitigasi atas risiko tersebut. Metode House of Risk ini pernah digunakan dalam jurnal yang berjudul "Studi Implementasi Model House of Risk (HOR) untuk Mitigasi Risiko Keterlambatan Material dan Komponen Impor pada Pembangunan Kapal Baru" oleh Zulia Dewi Cahyani, dkk pada tahun 2016.

Berdasarkan permasalahan yang dibahas sebelumnya, penulis tertarik untuk meneliti lebih jauh mengenai risiko apa saja yang akan ditanggung oleh PT Leschaco Logistic Indonesia.

\section{METODE PENELITIAN}

Masalah yang akan dipecahkan dalam penelitian ini adalah mengenai kesulitan mendapatkan space dari airline karena pelayanan ditangguhkan untuk tujuan atau dari Indonesia, dan gudang overload di airlines dan terjadinya cancel flight dari airlines secara mendadak. Permasalahan tersebut muncul karena covid-19 mengakibatkan seluruh operasional bandara menjadi ditangguhkan dengan memperhatikan kondisi kesehatan dunia karena penyebaran virus ini sangatlah cepat dan dapat mengendap di mana saja termasuk di barang yang akan dikirim oleh karena itu airlines menangguhkan seluruh operasionalnya dengan tujuan atau dari Indonesia sampai waktu yang tak ditentukan, serta beberapa airlines tidak menerima booking space kargo dikarenakan sudah full booking, akan tetapi ada beberapa airlines yang provide untuk tujuan atau dari Indonesia akan tetapi tariff yang dipasang dari airlines cukup tinggi, dan terkena limit pengiriman barang dan Penumpukan barang di airlines, dalam pengiriman impor barang dikirim menggunakan flight schedule pertama dan mendarat di bandara transit terlebih dahulu. Terjadinya gudang overload di airlines dikarenakan cancel flight dari airlines yang mendadak bisa dikarenakan force majeur, badai, cuaca buruk, dan tentunya kondisi Covid-19 yang dimana beberapa bandara tujuan tidak menerima kedatangan barang kargo ataupun penumpang ke tempat tujuannya tersebut dengan kondisi tersebut maka barang tersebut menumpuk di gudang airlines dan akan mengakibatkan banyak resiko seperti kehilangan barang, dan kerusakan barang.

Data diperoleh dengan cara melakukan wawancara untuk mengetahui proses penundaan penerbangan pengiriman barang saat Covid-19 dan informasi lainnya yang terkait dengan penelitian penulis. Wawancara dilakukan kepada karyawan yang secara langsung menangani dan bertanggung jawab pada kegiatan pengiriman barang sehingga diharapkan data yang diperoleh memiliki tingkat validitas yang tinggi. Penulis melakukan wawancara dengan Airfreight Office Supervisor, dan Airfreight Staff Import PT Leschaco Logistic Indonesia.

Penulis memilih metode pemecahan masalah yaitu metode house of risk yang merupakan salah satu alat pemecahan masalah yang bertujuan untuk mengidentifikasi, menganalisis, mengukur serta memitigasi risiko yang berpotensi timbul. Pemilihan metode pemecahan masalah didasarkan pada hubungan antara permasalahan yang ada dengan analisis yang akan dilakukan oleh penulis terkait dengan risiko-risiko pada penundaan penerbangan pengiriman barang saat Covid-19 PT Leschaco Logistic Indonesia.

\section{Gambar 1 Flowchart Rancangan Analisis HOR}

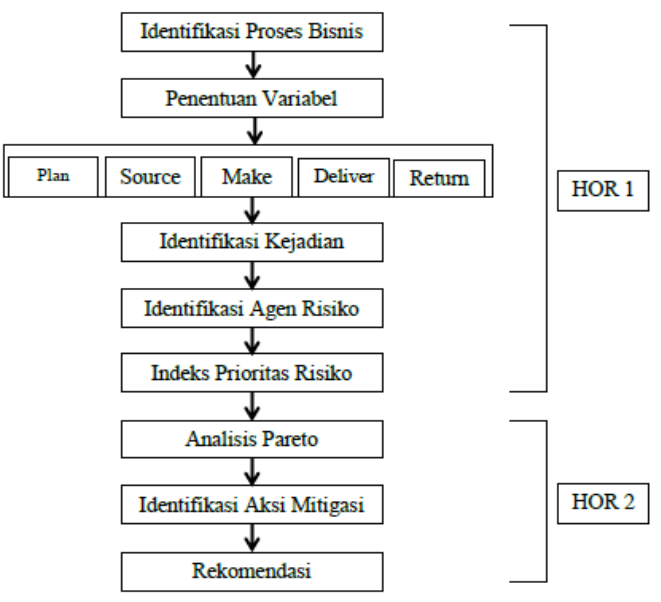

Langkah - langkah penyelesaian :

1. Identifikasi Proses Bisnis

2. Identifikasi Kejadian Risiko

3. Identifikasi Agen Risiko

4. Indeks Prioritas Risiko

5. Analisis Pareto 
6. Identifikasi Aksi Mitigasi

7. Rekomendasi

Penulis melakukan analisis terhadap hasil yang didapat dari pengolahan data HOR fase 1 dan HOR fase 2. Penulis akan mengetahui kejadian risiko dan agen risiko yang berpotensi timbul dalam proses penundaan penerbangan pengiriman barang saat Covid-19 dari gudang supplier menuju gudang pelanggan di PT Leschaco Logistic Indonesia, serta dapat mengetahui perancangan strategi mitigasi yang tepat dalam menangani agen risiko yang akan menjadi rekomendasi untuk PT Leschaco Logistic Indonesia.

\section{HASIL DAN PEMBAHASAN}

\section{Tabel 1 Seleksi Agen Risiko}

\begin{tabular}{|l|l|l|l|l|c|}
\hline Code & ARP & Ranking & $\begin{array}{l}\text { Kumulatif } \\
\text { ARP }\end{array}$ & $\begin{array}{l}\text { Kumulatif } \\
\text { ARP\% }\end{array}$ \\
\hline ARP1 & 2808 & 1 & 2808 & 8,83 & 8,83 \\
\hline ARP4 & 2754 & 2 & 5562 & 8,66 & 17,49 \\
\hline ARP18 & 2336 & 3 & 7898 & 7,35 & 24,84 \\
\hline ARP2 & 2160 & 4 & 10058 & 6,79 & 31,63 \\
\hline ARP30 & 2088 & 5 & 12146 & 6,57 & 38,20 \\
\hline ARP3 & 1944 & 6 & 14090 & 6,11 & 44,31 \\
\hline ARP5 & 1944 & 7 & 16034 & 6,11 & 50,43 \\
\hline ARP15 & 1896 & 8 & 17930 & 5,96 & 56,39 \\
\hline ARP16 & 1764 & 9 & 19694 & 5,55 & 61,94 \\
\hline ARP10 & 1512 & 10 & 21206 & 4,76 & 66,69 \\
\hline ARP17 & 1440 & 11 & 22646 & 4,53 & 71,22 \\
\hline ARP12 & 1281 & 12 & 23927 & 4,03 & 75,25 \\
\hline ARP23 & 1050 & 13 & 24977 & 3,30 & 78,55 \\
\hline ARP19 & 864 & 14 & 258597 & $8,27,27$ \\
\hline
\end{tabular}

Agen risiko prioritas ini akan diidentifikasi terkait aksi mitigasi yang tepat dalam penanganan risiko prioritas dengan menggunakan analisis pareto.

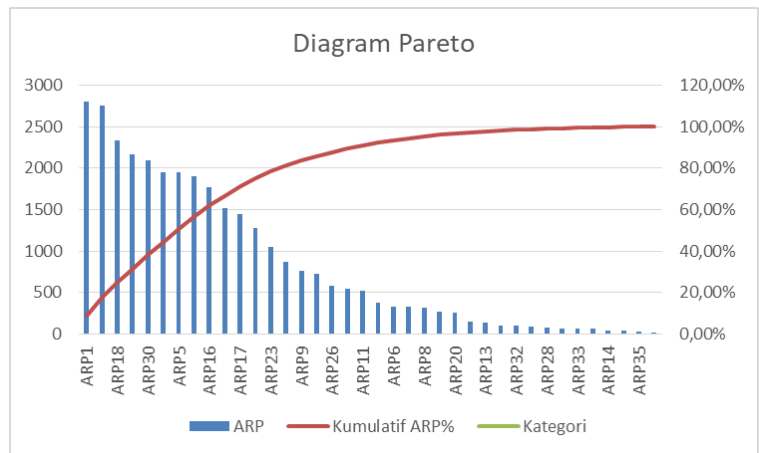

Gambar 2 Diagram Pareto

Penentuan agen risiko prioritas dilakukan dengan analisis pareto yang dikenal dengan hukum 80:20. Penerapan analisis pareto pada risiko yaitu $80 \%$ kerugian perusahaan diakibatkan oleh $20 \%$ risiko yang krusial. Dengan memfokuskan $20 \%$ risiko yang krusial, maka dampak risiko sebesar $80 \%$ dapat teratasi. Dari hasil yang di dapatkan berdasarkan perhitungan dengan menggunakan analisis pareto terdapat 13 agen risiko yang selanjutnya akan diidentifikasi terkait aksi mitigasi yang tepat dalam penangan agen risiko prioritas.

Identifikasi aksi mitigasi atau tindakan pencegahan (preventive action) untuk memitigasi agen risiko yang dapat memungkinkan untuk mengeliminasi atau mengurangi munculnya kemungkinan agen risiko. Kemudian ditentukan tindakan pencegahan (preventive action) untuk memitigasi agen risiko yang dapat memungkinkan untuk mengeliminasi atau menurunkan munculnya agen risiko. 
Tabel 2 Identifikasi Aksi Mitigasi

\begin{tabular}{|c|c|}
\hline Code & Preventive Action \\
\hline PA1 & $\begin{array}{l}\text { Mencari informasi kepada agent kemungkinan untuk } \\
\text { bisa melakukan pengiriman kargo barang atau hewan } \\
\text { hidup dan beserta term and condition }\end{array}$ \\
\hline PA2 & $\begin{array}{l}\text { Mengkomunikasikan kepada customer bahwa } \\
\text { barang tertahan di negara transit dikarenakan } \\
\text { lockdown, akan terjadi telat pengiriman barang }\end{array}$ \\
\hline PA3 & $\begin{array}{l}\text { Menawarkan untuk menggunakan jasa seafreight } \\
\text { kepada customer untuk menghindari jadwal fluktatif } \\
\text { dan penangguhan ke Indonesia }\end{array}$ \\
\hline PA4 & $\begin{array}{l}\text { Mengelompokkan barang urgent untuk dikirim } \\
\text { untuk menghindari limit dari airlines }\end{array}$ \\
\hline PA5 & $\begin{array}{l}\text { Menambah vendor trucking sesuai dengan } \\
\text { spesifikasi yang diharapkan }\end{array}$ \\
\hline PA6 & Mencari airlines yang tidak membatasi limit barang \\
\hline PA7 & Negosiasi rate dengan airlines \\
\hline PA8 & $\begin{array}{l}\text { Mempertahankan persentase penjualan dan } \\
\text { meningkatkan performa }\end{array}$ \\
\hline PA9 & $\begin{array}{l}\text { Menetapkan spesifikasi vendor trucking yang } \\
\text { memiliki DG license }\end{array}$ \\
\hline PA10 & $\begin{array}{l}\text { Melakukan evaluasi terhadap vendor trucking secara } \\
\text { berkala }\end{array}$ \\
\hline PA11 & $\begin{array}{l}\text { Melakukan reminder kepada pihak airlines secara } \\
\text { berkala }\end{array}$ \\
\hline PA12 & $\begin{array}{l}\text { Memberikan jangka waktu penerbangan bagi } \\
\text { airlines }\end{array}$ \\
\hline PA13 & Melakukan internal meeting secara berkala \\
\hline PA14 & Membuat checklist harian \\
\hline PA15 & Memberikan lingkungan kerja yang nyaman \\
\hline PA16 & $\begin{array}{l}\text { Melakukan monitoring serta evaluasi kerja per divisi } \\
\text { dan antar divisi }\end{array}$ \\
\hline PA17 & $\begin{array}{l}\text { Memberikan punishment, rewards, dan motivasi } \\
\text { kepada karyawan }\end{array}$ \\
\hline PA18 & $\begin{array}{l}\text { Menunda pengiriman sampai kondisi } \\
\text { memungkinkan }\end{array}$ \\
\hline PA19 & $\begin{array}{l}\text { Mengingatkan dan mencari informasi melalui agent } \\
\text { mengenai pembatasan barang pengiriman }\end{array}$ \\
\hline
\end{tabular}

Korelasi antara agen risiko dengan mitigasi risiko diperoleh dari hasil wawancara kepada responden utama perusahaan, setelah mendapatkan hasil analisis agen risiko prioritas yang terpilih.
Tabel 3 Korelasi antara Agen Risiko dengan Mitigasi Risiko

\begin{tabular}{|c|c|c|}
\hline $\begin{array}{c}\text { Agen } \\
\text { Risiko }\end{array}$ & $\begin{array}{l}\text { Preventive } \\
\text { Action }\end{array}$ & $\begin{array}{l}\text { Korelas } \\
\text { i }\end{array}$ \\
\hline \multirow{5}{*}{ ARP1 } & PA1 & 9 \\
\hline & PA2 & 9 \\
\hline & PA11 & 9 \\
\hline & PA12 & 3 \\
\hline & PA18 & 1 \\
\hline \multirow{3}{*}{ ARP4 } & PA3 & 9 \\
\hline & PA11 & 9 \\
\hline & PA12 & 9 \\
\hline \multirow{6}{*}{ ARP18 } & PA3 & 9 \\
\hline & PA4 & 3 \\
\hline & PA6 & 3 \\
\hline & PA11 & 1 \\
\hline & PA12 & 3 \\
\hline & PA19 & 3 \\
\hline ARP2 & PA19 & 9 \\
\hline \multirow{3}{*}{ ARP30 } & PA5 & 9 \\
\hline & PA9 & 9 \\
\hline & PA10 & 9 \\
\hline \multirow{2}{*}{ ARP3 } & PA6 & 9 \\
\hline & PA19 & 9 \\
\hline \multirow{2}{*}{ ARP5 } & PA11 & 9 \\
\hline & PA12 & 9 \\
\hline \multirow{3}{*}{ ARP15 } & PA1 & 3 \\
\hline & PA2 & 9 \\
\hline & PA18 & 1 \\
\hline ARP16 & PA2 & 9 \\
\hline \multirow{2}{*}{ ARP10 } & PA9 & 9 \\
\hline & PA10 & 9 \\
\hline \multirow{4}{*}{ ARP17 } & PA13 & 9 \\
\hline & PA15 & 9 \\
\hline & PA16 & 9 \\
\hline & PA17 & 9 \\
\hline \multirow{3}{*}{ ARP12 } & PA7 & 9 \\
\hline & PA8 & 3 \\
\hline & PA16 & 3 \\
\hline \multirow{4}{*}{ ARP23 } & PA14 & 9 \\
\hline & PA15 & 9 \\
\hline & PA16 & 9 \\
\hline & PA17 & 9 \\
\hline
\end{tabular}

Pengukuran total efektivitas dari semua aksi mitigasi risiko yang telah diusulkan. Perhitungan total effectiveness di atas dilakukan untuk setiap tindakan pencegahan (preventive action) aksi mitigasi. 
Tabel 4 Total Efektivitas Agen Risiko

\begin{tabular}{|l|l|}
\hline Code & $\begin{array}{l}\text { Total } \\
\text { Efektivitas }\end{array}$ \\
\hline PA1 & 30.960 \\
\hline PA2 & 58.212 \\
\hline PA3 & 45.810 \\
\hline PA4 & 7.008 \\
\hline PA5 & 6.804 \\
\hline PA6 & 24.504 \\
\hline PA7 & 11.529 \\
\hline PA8 & 3.843 \\
\hline PA9 & 32.400 \\
\hline PA10 & 32.400 \\
\hline PA11 & 69.890 \\
\hline PA12 & 57.714 \\
\hline PA13 & 12.960 \\
\hline PA14 & 9.450 \\
\hline PA15 & 22.410 \\
\hline PA16 & 22.410 \\
\hline PA17 & 26.253 \\
\hline PA18 & 4.704 \\
\hline PA19 & 43.944 \\
\hline
\end{tabular}

Pengukuran tingkat kesulitan penerapan aksi mitigasi (degree of difficulty) tujuan dari pengukuran ini yaitu untuk mengetahui derajat kesulitan untuk penerapan aksi mitigasi

\section{Tabel 5 Tingkat Kesulitan Penerapan Aksi Mitigasi}

\begin{tabular}{|l|c|}
\hline Code & $\begin{array}{c}\text { Tingkat } \\
\text { Kesulitan }\end{array}$ \\
\hline PA1 & 4 \\
\hline PA2 & 3 \\
\hline PA3 & 3 \\
\hline PA4 & 4 \\
\hline PA5 & 5 \\
\hline PA6 & 5 \\
\hline PA7 & 4 \\
\hline PA8 & 3 \\
\hline PA9 & 5 \\
\hline PA10 & 4 \\
\hline PA11 & 4 \\
\hline PA12 & 5 \\
\hline PA13 & 3 \\
\hline PA14 & 3 \\
\hline PA15 & 3 \\
\hline PA16 & 3 \\
\hline PA17 & 3 \\
\hline PA18 & 4 \\
\hline PA19 & 5 \\
\hline
\end{tabular}

Kalkulasi total efektivitas penerapan aksi mitigasi (effectiveness to difficulty) perhitungan ini dihitung https://ejurnal.poltekpos.ac.id/index.php/logistik/index berdasarkan perhitungan total effectiveness yang dibagi dengan degree of difficulty

\section{Tabel 6 Perhitungan Effectiveness to Difficulty}

\begin{tabular}{|l|c|}
\hline Code & ETDx \\
\hline PA1 & 7740 \\
\hline PA2 & 19404 \\
\hline PA3 & 15270 \\
\hline PA4 & 1752 \\
\hline PA5 & 1360,8 \\
\hline PA6 & 4901 \\
\hline PA7 & 2882 \\
\hline PA8 & 1281 \\
\hline PA9 & 6480 \\
\hline PA10 & 8100 \\
\hline PA11 & 17473 \\
\hline PA12 & 11543 \\
\hline PA13 & 4320 \\
\hline PA14 & 3150 \\
\hline PA15 & 7470 \\
\hline PA16 & 7470 \\
\hline PA17 & 8751 \\
\hline PA18 & 1176 \\
\hline PA19 & 8789 \\
\hline
\end{tabular}

Pengukuran skala prioritas aksi mitigasi, pemilihan strategi mitigasi oleh perusahaan dapat dilihat berdasarkan urutan dari ETD tertinggi ke ETD terendah, berikut merupakan skala prioritas aksi mitigasi:

Tabel 7 Pengukuran Skala Prioritas
\begin{tabular}{|l|c|c|}
\hline Code & ETD $\boldsymbol{x}$ & Peringkat \\
\hline PA2 & 19404 & 1 \\
\hline PA11 & 17473 & 2 \\
\hline PA3 & 15270 & 3 \\
\hline PA12 & 11543 & 4 \\
\hline PA19 & 8789 & 5 \\
\hline PA17 & 8751 & 6 \\
\hline PA10 & 8100 & 7 \\
\hline PA1 & 7740 & 8 \\
\hline PA15 & 7470 & 9 \\
\hline PA16 & 7470 & 10 \\
\hline PA9 & 6480 & 11 \\
\hline PA6 & 4901 & 12 \\
\hline PA13 & 4320 & 13 \\
\hline PA14 & 3150 & 14 \\
\hline PA7 & 2882 & 15 \\
\hline PA4 & 1752 & 16 \\
\hline PA5 & 1360 & 17 \\
\hline PA8 & 1281 & 18 \\
\hline PA18 & 1176 & 19 \\
\hline
\end{tabular}




\section{KESIMPULAN}

Dari hasil pengolahan data dan analisis data yang telah dilakukan dalam proses analisis flight delay pengiriman barang saat covid-19 di PT Leschaco Logistic Indonesia dengan metode House of Risk, dapat disimpulkan bahwa :

1. Terdapat 25 kejadian risiko (risk events) di PT Leschaco Logistic Indonesia yang teridentifikasi menggunakan model supply chain operation references (SCOR). Kejadian risiko ini tersebar pada setiap sub proses yaitu 4 kejadian risiko di bagian plan, 6 kejadian risiko di bagian source, 6 kejadian risiko di bagian make, 7 kejadian risiko di bagian deliver dan 2 kejadian risiko di return. Setiap kejadian risiko memiliki tingkat dampak (severity) yang berbeda-beda.

2. Identifikasi juga dilakukan untuk mengetahui agen risiko (risk egent) penyebab kejadian risiko. Satu agen risiko dapat menyebabkan lebih dari satu kejadian risiko. Terdapat 38 agen risiko yang teridentifikasi oleh penulis. Semua agen risiko tersebut diolah kembali untuk menentukan agen risiko yang prioritas dan non prioritas. Agen risiko prioritas sebanyak 13 agen risiko dan agen risiko non prioritas sebanyak 25. Agen risiko prioritas ini akan dijadikan input untuk pengolahan House of Risk fase

3.

4. Agen risiko prioritas harus diberikan tindakan pencegahan (preventive action) untuk memitigasi agen risiko yang dapat memungkinkan untuk mengeliminasi atau menurunkan munculnya agen risiko. Tindakan pencegahan yang dilakukan untuk memitigasi agen risiko prioritas sebanyak 19 aksi mitigasi. Satu tindakan pencegahan dapat memitigasi lebih dari satu agen risiko prioritas. Tindakan pencegahan yang tertinggi yaitu mengkomunikasikan kepada customer bahwa barang tertahan di negara transit dikarenakan lockdown, akan terjadi telat pengiriman barang (PA2) sedangkan tindakan pencegahan yang terendah yaitu menunda pengiriman sampai kondisi memungkinkan (PA18).

\section{REFERENSI}

Cahyani dkk (2016).Studi implementasi model house of risk (HOR) untuk mitigasi risiko keterlambtan material dan komponen impor pada pembangunan kapal baru.Jurnal Teknik ITS, Vol. 5, No.2, Hal. G52.

Geraldin dan Pujawan (2007).Manajemen Risiko dan aksi mitigasi untuk menciptakan rantai pasok yang robust.Jurnal Teknologi dan Rekayasa Teknik Sipil, Hal.53.
Hanafi, Mahmud M.2016.Manajemen Risiko.Yogyakarta:UPP STIM YKPN.

Indrawan, Rully, dan Yaniawati, Poppy. 2014. "METODOLOGI PENELITIAN Kuantitatif, Kualitatif, dan Campuran untuk Manajemen, Pembangunan, dan Pendidikan. Bandung : Refika Aditama.Lexzau, Scharbau. 2016."Leschaco Indonesia".

Nasution, M. Nur. 2003. "MANAJEMEN TRANSPORTASI". Jakarta : Ghalia Indonesia.

Pujawan Dan Mahendrawathi Er.2017.Supply Chain Management.Surabaya:Guna Widya. 